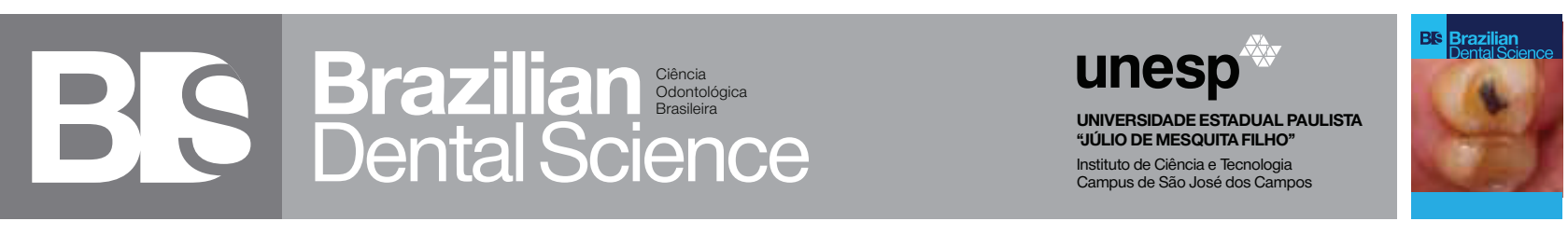

\title{
Cytotoxicity of non-vital dental bleaching agents in human gingival fibroblasts
}

Avaliação da citotoxicidade de agentes clareadores de uso interno sobre fibroblastos gengivais humanos

Aletéia Massula FERNANDES ${ }^{1}$, Marcia Martins MARQUES ${ }^{1}$, Samira Esteves Afonso CAMARGO ${ }^{1}$, Paula Elaine CARDOSO $^{1}$, Carlos Henrique Ribeiro CAMARGO ${ }^{1}$, Marcia Carneiro VALERA

1 - School of Dentistry, Institute of Science and Technology, UNESP - Univ. Estadual Paulista, Department of Restorative Dentistry - São José dos Campos, SP, Brazil.

\section{ABSTRACT}

Objective: The aim of this study was to compare several non-vital dental bleaching agents for their in vitro cytotoxicity to human gingival fibroblasts primary cell line. Methods: The cells were cultivated in DMEM and were seed in plates of 96 wells; then, it was exposed to the conditioned medium according to the experimental groups $(n=12)$ : $\mathbf{G 1}$ - SP (sodium perborate) + distilled water; G2 - SP + 20\% CP (carbamide peroxide); G3 - 20\% CP; G4 - SP + 35\% HP (hydrogen peroxide); G5 - 35\% HP. In the control group $(n=12)$, corresponded to the curve of cell growth and viability, the cells did not receive any treatment. Cell viability was measured photometrically using a MTT assay after a $24 \mathrm{~h}$ and $48 \mathrm{~h}$ of exposure period. Data were submitted to ANOVA and Tukey's tests. Results: All the experimental groups presented high cytotoxicity statically in comparison to the control group. The rank of the most to the least toxic material after 24 h was: $\mathrm{SP}+\mathrm{DW}>$ $35 \% \mathrm{PH}>\mathrm{PS}+20 \% \mathrm{PC}>\mathrm{PS}+35 \% \mathrm{PH}>$ 20\% PC; and after 48 h was: SP + DW $>$ PS $+20 \%$ PC $>35 \%$ PH $>$ PS + 35\% PH > 20\% PC. Conclusion: All the bleaching agents had presented cytotoxicity effects, reducing significantly the cell viability, however, in the conditions that the study was conducted the association of sodium perborate with distilled water was the most toxic bleaching agent.

\section{KEYWORDS}

Citotocixity; Bleaching agent; Fibroblasts; Cell culture.

\section{RESUMO}

Objetivo: O objetivo deste estudo foi comparar a citotoxicidade de agentes clareadores de uso interno em linhagem primária de fibroblastos humanos. Material e Método: As células foram cultivadas em meio DMEM e semeadas em placas de 96 poços. Em seguida, foram expostas aos meios de cultura condicionados de acordo com os grupos experimentais $\quad(\mathrm{n}=12): \mathbf{G} \mathbf{1}$ - PS (perborato de sódio) + água destilada; G2 - PS + PC 20\% (peróxido de carbamida); G3 - PC 20\% ; G4 - PS + PH 35\% (peróxido de hidrogênio); G5 - PH 35\%. No grupo controle $(n=12)$, correspondente à curva de crescimento e viabilidade celular, as células não receberam nenhum tratamento. A viabilidade celular foi verificada por espectofotômetro utilizando o ensaio de MTT, após um período de 24 e 48 h de exposição aos agentes clareadores. Os dados foram submetidos aos testes de ANOVA e Tukey. Resultados: Todos os grupos experimentais apresentaram alta citotoxicidade em relação ao grupo controle. O rank de citotoxicidade dos agestes clareadores após 24 h foi: PS + AD > PH 35\% > PS + PC $20 \%>$ PS + PH $35 \%>$ PC $20 \%$ e após 48 h foi: $\mathrm{PS}+\mathrm{AD}>\mathrm{PS}+\mathrm{PC} 20 \%>35 \% \mathrm{PH}>\mathrm{PS}+$ PH 35\% > 20\% PC. Conclusão: Todos os agentes clareadores apresentaram efeitos citotóxicos, reduzindo significativamente a viabilidade da celular.Entretanto, nas condições em que o estudo foi conduzido a associação do perborato de sódio com água destilada, foi o agente clareador mais tóxico.

\section{PALAVRAS-CHAVE}

Citotoxicidade; Agente de branqueamento; Fibroblastos; Cultura celular. 


\section{INTRODUCTION}

Ton-vital tooth bleaching was first described 1 in 1967 by Chandra [1], and various types of agents such as chloride, sodium hypochlorite, sodium perborate and hydrogen peroxide has been used, alone, in combination and with or without heat activation [2].

Tooth bleaching is based on the use of the hydrogen peroxide (HP), carbamide peroxide (CP) and sodium perborate (SP). Thus, the hydrogen peroxide is the active agent during bleaching process, being applied directly or produced by a chemical reaction from sodium perborate or carbamide peroxide. Hydrogen peroxide acts as a strong oxidizing agent producing free radicals, reactive molecules and hydrogen peroxide ions [3].

Tooth permeability to bleaching agents occurs due to its low molecular weight and the ability of denature proteins, allowing the penetration of hydrogen peroxide to the pulp chamber and periodontal tissue [4,5]. Several authors reported that bleaching agents can penetrate in the dentinal tubules and initiated an inflammatory process which might promote a cervical external root resorption [6] after non-vital dental bleaching in teeth with or without defects in the cementumenamel junction $[7,8]$.

It is known that the hydrogen peroxide as others oxidative agents may cause cellular and tissue destruction [9], beyond several damage to human fibroblasts [10], which are the predominant cells in periodontal tissue [11].

Also, according to Laroui et al. [12], the hydrogen peroxide is able to interact with DNA, promoting oxidative damage on it. DNA damage has been recognized as the main cause of cell death and mutation in aerobic organisms [13].

Therefore, studies that evaluate the biocompatibility of bleaching agents are required to indicate a safely bleaching procedure. The cytotoxicity test has been used as a viable and commonly alternative for assessment of the biological material, providing fast and accurate results.

The aim of this study was to evaluate the cytotoxicity of bleaching agents used for endodontically treated teeth on gingival human fibroblasts.

\section{MATERIALS AND METHOD}

This study was conducted under approval of the Ethical Committee of the School of Dentistry of the São Paulo State University (process no. 024/2009).

\section{Experimental groups}

The following groups were used: G1Sodium perborate mixed with distilled water (Byoformula, São José dos Campos, SP, Brazil) in ratio 2:1 to form a paste (SP + H2O); G2Sodium perborate (Byoformula, São José dos Campos, SP, Brazil) mixed with $20 \%$ carbamide peroxide (Opalescence PF Ultradent, South Jordan, Utah, USA) (SP + 20\% CP); G3- 20\% Carbamide peroxide (Opalescence PF Ultradent, South Jordan, Utah, USA) (20\% CP); G4Sodium perborate (Byoformula, São José dos Campos, SP, Brazil) mixed with 35\% hydrogen peroxide (Opalescence Endo Ultradent, South Jordan, Utah, USA) (SP + 35\% HP) and G535\% Hydrogen peroxide (35\% HP) (Opalescence Endo Ultradent, South Jordan, Utah, USA). The control group corresponded to the cell culture without application of any bleaching agents.

\section{Culture medium conditioning}

In order to obtain conditioned medium, the bleaching agents were placed in contact with the culture medium (DMEM) during $30 \mathrm{~min}$ at $37{ }^{\circ} \mathrm{C}$ and $5 \% \mathrm{CO}_{2}$, using $0.4 \mathrm{~g}$ of each agent for $2 \mathrm{ml}$ of fresh medium, according to the America Society for Testing Materials [14].

\section{Cytotoxicity testing}

Primary cell line obtained from human gingival fibroblast was used in cell culture assay. These cells were cultured in DMEM (Dulbecco's Modified Eagle Medium) supplemented by $10 \%$ fetal bovine serum (Cultilab, Campinas, SP, Brazil) and $1 \%$ antimycotic-antibiotic solution $(10,000$ units of penicillin, $10 \mathrm{mg}$ of streptomycin and $25 \mu \mathrm{g}$ of amphotericin B per $\mathrm{ml}$ in $0.9 \%$ sodium chloride; Sigma Aldrich Co., Germany) at $37^{\circ} \mathrm{C}$ and $5 \% \mathrm{CO}_{2}$. Cultures were supplied with fresh medium every other day. Cells between the 5th and 10th passages were used in all experimental procedures. 
After cell culture, in each well of a 96well plate (Prolab, São Paulo, Brazil), 2 x 103 cells were seeded and incubated for $24 \mathrm{~h}$ at $37^{\circ} \mathrm{C}$. Then, the cell cultures were exposed to $200 \mu \mathrm{l}$ of the conditioned medium of the bleaching agents and $200 \mu \mathrm{l}$ of medium (untreated control) during $30 \mathrm{~min}$. After that period, the conditioned medium was replaced for fresh medium and then, cell survival was determined using a MTT assay after 24 and $48 \mathrm{~h}$.

\section{Analysis of cell viability and growth (MTT assay)}

It was used four specimens of each group for two periods ( $24 \mathrm{~h}$ and $48 \mathrm{~h}$ ) in three independent experiments to evaluate cell metabolic activity by the methyltetrazolium (MTT) assay, which determines the activity of the succinate dehydrogenase (SDH) enzyme produced by the mitochondria of viable cells.

For this, $100 \mu \mathrm{l}$ of MTT solution (0.5 mg methyltetrazolium salt in $1 \mathrm{ml}$ PBS, Sigma Aldrich Co., Germany) was placed in each well of the 96-well plate and were incubated at $37{ }^{\circ} \mathrm{C}$ for $1 \mathrm{~h}$. After this period, MTT solution was removed and replaced by $100 \mu \mathrm{l}$ of DMSO (Sigma Aldrich Co., Germany), to dissolve the blue crystals of formazan present in the cells resulting from the cleavage methyltetrazolium salt by SDH enzyme produced in the mitochondria of the viable cells. After shaking for $10 \mathrm{~min}$, the plates were taking to a multi-well spectrophotometer (Asys Hitech $\mathrm{GmbH}$, Austria) to measure the optical density at $492 \mathrm{~nm}$.

Optical density readings were normalized to untreated control cultures $(=100 \%)$, and differences between median values were statistically analyzed using the ANOVA and Tukey's tests at the 0.05 level of significance.

\section{RESULTS}

The mean and standard deviation of cell viability for the control and experimental groups, expressed in percentage, are show in Figure 1, according to the exposure time period ( $24 \mathrm{~h}$ and $48 \mathrm{~h}$ ).

The MTT assay indicated that the cell viability of control group was higher than all experimental groups. According to experimental groups, the most toxic material was sodium perborate (SP) + distilled water, exhibiting the cell viability of $6.58 \%$ and $2.10 \%$, after 24 $\mathrm{h}$ and $48 \mathrm{~h}$, respectively. On the other hand, $20 \%$ carbamide peroxide (20\% CP) showed the highest cell viability, $42.46 \%$ (after $24 \mathrm{~h}$ ) and $42.65 \%$ (after $48 \mathrm{~h}$ ).

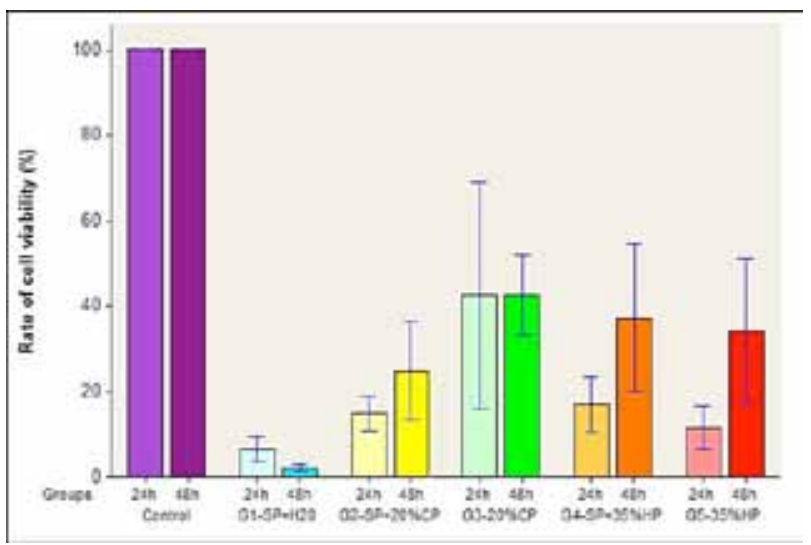

Figure 1 - Cytotoxicity of bleaching agents in human gingival fibroblast cells (FMM1) after two time exposure, and cellular viability in treated and untreated cell cultures was determined in quadruplicate in three independent experiments $(n=12)$. Bars represent medians plus 25\% and $75 \%$ percentiles.

The ANOVA test revealed that the cell viability of control group was statistically significant different compared to all experimental groups in both time of evaluation ( $\mathrm{p}=0.001<0.05)$.

The Tukey's test was used to compare the cell viability of experimental groups in both time of evaluation, and it showed that after $24 \mathrm{~h}$, the only group that was statistically different was G3 (20\% $\mathrm{CP}$ ), while after $48 \mathrm{~h}$, was $\mathrm{G} 1\left(\mathrm{SP}+\mathrm{H}_{2} \mathrm{O}\right)$ (Tables 1 and 2). 
Table 1 - Tukey's test for experimental groups after $24 \mathrm{~h}$

\begin{tabular}{|c|c|}
\hline Experimental Groups & Homogeneous Groups* \\
\hline Group 3 (20\% CP) & A \\
\hline Group 4 (SP + 35\% HP) & B \\
\hline Group 2 $(\mathrm{SP}+20 \% \mathrm{CP})$ & $\mathrm{B}$ \\
\hline Group 5 $(35 \% \mathrm{HP})$ & $\mathrm{B}$ \\
\hline Group 1 $(\mathrm{SP}+\mathrm{H} 20)$ & $\mathrm{B}$ \\
\hline * Mean values followed by different letters correspond to statically \\
different data.
\end{tabular}

Table 2 - Tukey's test for experimental groups after $48 \mathrm{~h}$

\begin{tabular}{|c|c|}
\hline Experimental Groups & Homogeneous Groups* \\
\hline Group 3 (20\% CP) & $\mathrm{A}$ \\
\hline Group $4(\mathrm{SP}+35 \% \mathrm{HP})$ & $A$ \\
\hline Group 2 (SP + 20\% CP) & $A$ \\
\hline Group 5 (35\% HP) & $A$ \\
\hline Group 1(SP + H20) & B \\
\hline
\end{tabular}

\section{DISCUSSION}

This study evaluated the cytotoxicity of bleaching agents in human cell culture. It is relevant to know that hydrogen peroxide acts as a strong oxidizing agent releasing free radicals, reactive oxygen molecules and hydrogen peroxide ions [15]. These reactive molecules split the longchained, dark-colored chromophore molecules into smaller, less colored, and more diffusible molecules [3]. The hydrogen peroxide through the formation of oxidative radicals seems to be able to cause damage to the structures of DNA and cell death [16].

Discolored non-vital teeth with endodontic treatment has an increase of the dentin permeability and decrease of the dentin microhardness, caused by the use of irrigating solutions and the attrition of the instruments on the walls of the root canal $[17,18]$. The hydrogen peroxide that is the main component of all bleaching agents, can diffuse through dentin and cementum and reaches periodontal tissues $[5,19,20]$, causing damage effects from mild inflammation to external cervical root resorption [6].

It is believed that the diffusion of hydrogen peroxide from the pulp chamber to the external root surface occurs and has more significance if the tooth has a defect in the cementum-enamel junction (CEJ) [7]. However, Palo et al. [8], found that ions of bleaching agents penetrates through dentin and cementum, even in teeth which the scanning electron microscopy (SEM) analysis detected no failures or discontinuities at the CEJ.

This study was conducted in an in vitro cell culture model, which is considered an initial test for the evaluation of materials used in Dentistry. Two types of cells can be used: permanent cell lines derived from type-culture collections (or from commercial sources) or primary cells derived from explants and established in each individual laboratory [21]. In this study a primary cell line was used, since it has a specific metabolic potential similar to the target cells and, therefore, it is closer to the in vivo situation $[21,22]$.

In vitro cell culture model allows various methods to apply the bleaching agents on the cell cultures. Some authors reported the use of serial dilutions from the hydrogen peroxide [2224], however, Aren [25] used the cell culture medium conditioned with the bleaching agent prior to application on cells.

In this study, the cell culture medium conditioning was used. This method can be indicated for analyzing substances released from the bleaching agents during the time in contact with cell culture medium. After this period, only the conditioned medium is placed in contact with the cells, avoiding direct contact with these bleaching agents [14]. In this study, the conditioned medium remained in contact with the cells for just $30 \mathrm{~min}$, because pilot studies have shown that after this period, the bleaching agents becomes extremely toxic, making it impossible to realize this type of research. This data is according with the study of Dantas et al. [26], that placed the conditioned medium is contact with the cells for $40 \mathrm{~min}$. Moreover, Soares et al. [27], evaluated the cytotoxicity of $35 \%$ Hydrogen peroxide and 
different periods of contact of the gel with odontoblast-like cells (MDPC-23) and conclude that cytotoxic effects were proportional to the contact time of the bleaching gel.

A tetrazolium-based colorimetric (MTT) assay is widely used as a cytotoxicity test in cultured cells due to this technique depends on the capacity of living cells to reduce tetrazolium salt [3-(4,5-dimethylthiazol-2-yl)-2,5-diphenyltetrazolium bromide] to a formazan crystal in their metabolizing mithochondria [28]. This test has been used by many authors in order to evaluate the cytotoxicity of various materials for application in Dentistry [29-32]. The MTT assay is reported to have several advantages including the fast analyses, measurements and management of many samples [28].

The sodium perborate (SP) associated with distilled water has been used as a safe bleaching agent for many authors [33,34], in this study it was considerate the most toxic agent. This cytotoxic action of SP + distilled water could be explained by the physical form of this association. During the conditioned medium procedure, the paste of sodium perborate with distilled water became more soluble than other bleaching agents in gel form, thus releasing a higher amount of reactive ions that came into contact with the cells.

The percentage of cell viability of $20 \%$ carbamide peroxide associated with sodium perborate was lower than the $20 \%$ carbamide peroxide with non-association. This probably indicates that the sodium perborate potentiated the cytotoxic effect of the bleaching gel and showed that its physical vehicle dissociation characteristics can interfere in the toxicity.

Despite of the $35 \%$ hydrogen peroxide gel is well known as a bleaching agent used in the techniques of tooth whitening, in this study it showed a significant decrease of cell viability after $24 \mathrm{~h}$. These results can be complemented by Ribeiro et al. [35], who studied the genotoxicity of bleaching agents and concluded that the 35\% hydrogen peroxide was extremely damaging to cellular DNA.

The values of cell viability in cell culture without bleaching agent application (control group) were significantly higher than in the experimental groups in both periods evaluation.
The cells continued to grow and multiply throughout the experiment, since the values of viability found after $48 \mathrm{~h}$ was higher than in $24 \mathrm{~h}$. For the experimental groups, it could be observed that the cells had recovered partially, since the cell viability of these groups, except for group SP + distilled water, was lower in the evaluation period of $24 \mathrm{~h}$ compared to $48 \mathrm{~h}$. These results are in agreement with Kinomoto et al. [23], who evaluate the cytotoxicity of bleaching agents in cell culture, also found that initially $(24 \mathrm{~h})$, the $30 \%$ hydrogen peroxide was more toxic than SP, however, after $72 \mathrm{~h}$, SP maintained its cytotoxic effect, showing higher values than 30\% hydrogen peroxide. These results indicate that the sodium perborate paste is able to remain active even after long periods.

Our results are according to others studies $[22,24,25]$, which found a reduction in the growth and viability of cells after exposure to bleaching agents, using different methods and confirmed the cytotoxic effect of these agents. Also, Lima et al. [29] that used a similar method of our study, reported that a low concentration of bleaching agent $(0.1 \%$ carbamide peroxide) was able to induce cytotoxicity effects in odontoblasts (MDPC-23), reducing its metabolism by about $80 \%$ compared with the control group.

Non-vital dental bleaching has proved a major technique for recovery of aesthetics and harmony of the smile. However, it statement should be extremely cautious, since the results found in this and other studies indicate that bleaching agents may cause toxicity to cells and their genetic material [35]. The selection and appointment of a bleaching agent should be based on its biocompatibility, since many studies have shown that bleaching agents have similar aesthetic results $[19,36]$.

Therefore, other studies using different methodologies should be performed to confirm the cytotoxicity of bleaching agents, especially sodium perborate which is a product in powder form.

\section{CONCLUSION}

According to the methodology of this study, we can conclude that all bleaching agents tested were cytotoxic, decreasing significantly the metabolism and cell viability. The association of sodium perborate with distilled water was the most cytotoxic bleaching agent and the 20\% carbamide peroxide was the least. 


\section{REFERENCES}

1. Chandra S. Bleaching of discoloured non-vital teeth. J Indian Dent Assoc. 1967 0ct;39(10):157-61.

2. Howell RA. Bleaching discoloured root-filled teeth. Br Dent J. 1980;148(6):159-62.

3. Dahl JE, Pallesen U. Tooth bleaching--a critical review of the biological aspects. Crit Rev Oral Biol Med. 2003;14(4):292-304.

4. Benetti AR, Valera MC, Mancini MN, Miranda CB, Balducci I. In vitro penetration of bleaching agents into the pulp chamber. Int Endod J. 2004;37(2):120-4.

5. Gökay 0, Ziraman F, Cali Asal A, Saka OM. Radicular peroxide penetration from carbamide peroxide gels during intracoronal bleaching. Int Endod J. 2008;41(7):556-60.

6. Harrington GW, Natkin E. external resoption associated with bleaching of pulpless teeth. J Endod. 1979;5(11):344-8.

7. Rotstein I, Torek Y, Misgav R. Effect of cementum defects on radicular penetration of $30 \% \mathrm{H} 202$ during intracoronal bleaching. J Endod. 1991;17(5):230-3.

8. Palo RM, Valera MC, Camargo SE, Camargo CH, Cardoso PE, Mancini MN, et al. Peroxide penetration from the pulp chamber to the external root surface after internal bleaching. Am J Dent. 2010 Jun;23(3):171-4.

9. Halliwel B, Gutteridge JMC. Oxigen toxicity, oxygen radicals, transition metals and disease. Biochem J. 1984;219(1):1-14.

10. Simon RH, Scoggin $\mathrm{CH}$, Patterson D. Hydrogen peroxide causes the fatal injury to human fibroblast exposed to oxygen radicals. J Biol Chem. 1981;256(14):7181-6.

11. Tipton DA, Braxton SD, Dabbous MK. Effects of a bleaching agent on human gingival fibroblasts. J Periodontol. 1995;66(1):7-13.

12. Laroui P, Desai SD, Li TK, Liu AA, Liu LF. Hydrogen peroxide induces topoisomerase 1-mediated DNA damage and cell death. J Biol Chem. 2004;279:14587-94.

13. Slupphaug G, Kavli B, krokan HE. The interacting pathways for prevention and repair of oxidative DNA damage. Mutat Res. 2003;531(1-2):231-51.

14. Cavalcanti BN, Rode SM, Marques MM. Cytotoxicity of substances leached or dissolved from pulp capping materials. Int Endod J. 2005;38(8):505-9.

15. Gregus Z, Kallassen CD. Mechanisms of toxicity. In: Klaassen CD, editor. Cassarett and Dull's Toxicology, the basic science of poisons. New York: McGraw-Hill; 1995. p. 35-74.

16. International Agency on Research on Cancer. Monographs on the evaluation of carcinogenic risks to humans. Re-evaluation of some organic chemicals, hydrazine and hydrogen peroxide. Lyon: France; 1999.

17. Rotstein I, Dankner E, Goldman A, Heling I, Stabholz A, Zalkind M. Histochemical analysis of dental hard tissues following bleaching. J Endod. 1996;22(1):23-6.

18. Oliveira DP, Teixeira EC, Ferraz CC, Teixeira FB. Effect of intracoronal bleaching agents on dentin microhardness.J Endod. 2007;33(4):460-2.

19. Lee GP, Lee MY, Lum S0, Poh RS, Lim KC. Extraradicular diffusion of hydrogen peroxide and $\mathrm{pH}$ changes associated with intracoronal bleaching of discoloured teeth using different bleaching agents. Int Endod J. 2004;37(7):500-6.

20. Palo R, Bonetti-Filho I, Valera M, Camargo C, Camargo S, MouraNetto $C$, et al. Quantification of peroxide ion passage in dentin, enamel, and cementum after internal bleaching with hydrogen peroxide. Oper Dent. 2012 Nov-Dec;37(6):660-4.

21. Schmalz G. Use of cell cultures for toxicity testing of dental materials-advantages and limitations. J Dent. 1994;22(Suppl 2):S6-11.

22. Koulaouzidou E, Lambrianidis T, Konstantinidis A, Kortsaris AH. In vitro evaluation of the cytotoxicity of a bleaching agent. Endod Dent Traumatol. 1998;14(1):21-5.

23. Kinomoto Y, Carnes Jr DL, Ebisu S. Cytotoxicity of intracanal bleaching agents on periodontal ligament cells in vitro. J Endod. 2001;27(9):574-7.

24. Hanks CT, Fat JC, Wataha JC, Corcoran JF. Cytotoxicity and dentin permeability of carbamide peroxide and hydrogen peroxide vital bleaching materials, in vitro. J Dent Res. 1993;72(5):931-8.

25. Aren G. In vitro effects of bleaching agents on FM3A cell line. Quintessence Int. 2003;34(5):361-5.

26. Dantas CM, Vivan CL, Ferreira LS, Freitas PM, Marques MM. In vitro effect of low intensity laser on the cytotoxicity produced by substances released by bleaching gel. Braz Oral Res. 2010 Oct-Dec;24(4):460-6.

27. Soares DG, Ribeiro AP, da Silveira Vargas F, Hebling J, de Souza Costa CA. Efficacy and cytotoxicity of a bleaching gel after short application times on dental enamel. Clin Oral Investig. 2012 Dec 6. [Epub ahead of print]

28. Kim E, Jeon IS, Kim JW, Kim J, Jung HS, Lee SJ. An MTT based method for quantification of periodontal ligament cell viability. Oral Diseases. 2007;13(5):495-9.

29. Lima AF, Lessa FC, Gasparoto Mancini MN, Hebling J, de Souza Costa CA, Marchi GM. Cytotoxic effects of different concentrations of a carbamide peroxide bleaching gel on odontoblast-like cells MDPC-23. J Biomed Mater Res B Appl Biomater. 2009;90(2):907-12.

30. Koh T, Machino M, Murakami Y, Umemura N, Sakagami H Cytotoxicity of dental compounds towards human oral squamous cell carcinoma and normal oral cells. In Vivo. 2013 Jan-Feb;27(1):85-95.

31. Kierklo A, Pawi ska M, Tokajuk G, Pop awska B, Bielawska A. Cytotoxicity evaluation of three light-cured dentin adhesive materials on human gingival fibroblasts, ex vivo. Adv Med Sci. 2012;57(2):385-90. doi: 10.2478/v10039-012-0038-2.

32. De Melo WM, Maximiano WM, Antunes AA, Beloti MM, Rosa AL, de Oliveira PT. Cytotoxicity testing of methyl and ethyl 2-cyanoacrylate using direct contact assay on osteoblast cell cultures. J Oral Maxillofac Surg. 2013 Jan;71(1):35-41.

33. Weiger R, Kuhn A, Löst C. Radicular penetration of hydrogen peroxide during intra-coronal bleaching with various forms of sodium perborate. Int Endod J. 1994;27(6):313-7.

34. Attin T, Paqué F, Ajam F, Lennon AM. Review of the current status of tooth whitening with the walking bleach technique. Int Endod J. 2003;36(5):313-29. 
35. Ribeiro DA, Marques ME, Salvadori DM. Assesment of genetic damage induced by dental bleaching agents on mouse lymphoma cells by using single cell gel (comet) assay. J Oral Rehabil. 2005;32(10):766-71.
36. Souza-Zaroni WC, Lopes EB, Ciccone-Nogueira JC, Silva RC. Clinical comparison between the bleaching efficacy of $37 \%$ peroxide carbamide gel mixed with sodium perborate with established intracoronal bleaching agent. Oral Surg Oral Med Oral Pathol Oral Radiol Endod. 2009;107(2):43-7.

\section{Aletéia Massula Fernandes \\ (Corresponding author)}

Engenheiro Francisco José Longo, 777,

São Dimas.

CEP:.12245000 São José dos Campos -

São Paulo- Brazil.

Received: 2013 Feb 14

e-mail: aleteia.fernandes@hotmail.com

Accepted: 2013 Mar 28 